\title{
Usage of probiotic in country-type broiler's chicken diet and its effects over the carcass yield, morphology and the gastrointestinal pH
}

\author{
Uso de probiótico em dietas de frangos tipo caipira e seus efeitos sobre o rendimento \\ de carcaça, a morfologia e o pH gastrointestinal
}

\author{
VALENTIM, Jean Kaique ${ }^{*}$; DE PAULA, Karynne Luana Chaves ${ }^{1}$; GERALDO, \\ Adriano $^{2}$; MIRANDA, Diogo Alvarenga ${ }^{2}$; ANTUNES, Hellen Cristina Ferreira ${ }^{1}$; \\ LEMKE, Sara Santana Ramos²; GONZAGA, Poliana Rodrigues do Nascimento²; \\ CHAVES, Claudiane Aparecida Rocha ${ }^{2}$
}

${ }^{1}$ Universidade Federal dos Vales do Jequitinhonha e Mucuri, Departamento de Zootecnia, Diamantina, Minas Gerais, Brasil.

${ }^{2}$ Instituto Federal de Minas Gerais, Bambuí, Minas Gerais, Brasil.

*Endereço para correspondência: kaique.tim@hotmail.com

\section{SUMMARY}

This study had as an objective to evaluate the carcass yield, morphology and intestinal $\mathrm{pH}$ of male country hick broilers raised on Tifton- 85 pickets, fed with commercial probiotic supplemented ration. A total of 210 one-day-old males broiler's chicken from the Peeled Neck lineage were raised in experimental boxes on a conventional shed until 30 days of age, and from 30 to 90 days of age they had access to Tifton-85 pickets (Cynodonspp.). The carcass yield variables evaluated were live weight at 90 days, carcass weight (with foot, neck and head), carcass weight (without foot, neck and head), thigh, chest, wings, edible viscera, inedible viscera, abdominal fat, $\mathrm{pH}$, length and weight of the gastrointestinal tract compartments (gut, duodenum, jejunum, ileus, proventriculus, gizzard, and cecum). All data went through analysis of variance, and the means of the treatments were compared by the F test with $5 \%$ of probability. Variables of carcass yield, primary and secondary cuts, length, weight and $\mathrm{pH}$ of gastrointestinal tract compartments were not influenced $(\mathrm{P}>0.05)$ by treatments with and without probiotic addition. Inclusion of $300 \mathrm{~g} / \mathrm{ton}$ of the probiotic Bacillus subtilis DSM 15,544 in broiler's chicken from the Peeled Neck lineage had no influence over the carcass yield, $\mathrm{pH}$ and morphology of the gastrointestinal compartments of the birds in the period and levels in the present experiment. The sanitary challenge was not enough to demonstrate the effectiveness of probiotic action.

Keywords: additives, alternative poultry, Bacillus subtillis, noble cuts

\section{RESUMO}

Objetivou-se com este trabalho avaliar o rendimento de carcaça e $\mathrm{pH}$ intestinal de frangos coloniais machos criados em piquetes com Tifton85 , alimentados com ração suplementada com probiótico comercial. Foram utilizados 210 pintos de corte de um dia, machos, da linhagem Pescoço Pelado, criados em boxes experimentais em galpão convencional até os 30 dias de idade, e de 30 a 90 dias tiveram acesso a piquetes de Tifton-85 (Cynodonspp.). $\mathrm{O}$ delineamento experimental utilizado foi inteiramente casualizado, com dois tratamentos (ração convencional e ração convencional suplementada com probiótico "Bacillus subtillis DSM 15.544") e cinco repetições, contendo 21 aves por tratamentos. As variáveis de rendimento da carcaça avaliadas foram peso vivo aos 90 dias (PV), peso de carcaça (com pé, pescoço e cabeça), peso da carcaça (sem pé, pescoço e cabeça), coxa, sobrecoxa, peito, asas, vísceras comestíveis,vísceras não comestíveis, gordura abdominale o $\mathrm{pH}$ dos compartimentos do trato gastrointestinal (papo, duodeno, jejuno, íleo, proventrículo, moela, ceco). Os dados foram submetidos à análise de variância, 
e as médias dos tratamentos foram comparadas pelo teste $\mathrm{F}$ a $5 \%$ de significância. As variáveis de rendimento de carcaça, cortes primários, secundários e $\mathrm{pH}$ das vísceras não foram influenciadas $(\mathrm{P}>0,05)$ pelos tratamentos com e sem adição de probiótico. Presumiu-se que o desafio sanitário não foi suficiente para demonstrar efeitos do probiótico sobre as variáveis de carcaça e $\mathrm{pH}$ dos compartimentos intestinais.

Palavras-chave: aditivos, avicultura alternativa, Bacillus subtillis, cortes nobres

\section{INTRODUCTION}

Raising country-type chicken and hens is a tradition amid great part of Brazilians that live on either the countryside or urban area. The production of these animals is designated to the familiar consumption, performing an important part on the subsistence and acting as a source of emergency income to the rural producer.

An increase in the production contributed for the competition among the producer companies, which every day search for a differentiated products and better quality to attend the consumer's exigencies. Consumers has been looking for natural products, such as chickens raised in the open, with decreased developing speed, late slaughter and rations that will not include medicines and/or growth promoters (NAZARENO et al., 2016).

On the poultry sector, raising countrytype birds is one of the most promising segments. Current lineages present some differentiated sensorial characteristics in comparison to the commercial hick broilers of fast grow, for instance: savor, coloring, meat constancy, etc. (TAKAHASHI et al., 2006).

Federal supervision organs as MAPA (Ministry of Agriculture, Livestock and
Purveyance) requires that broiler's chicken diets will be free from antibiotics and development improvers, products those that are present on the conventional raisins system.

Lately the research organizations and nutrition industries has been working over the effects of alimentary supplementation in order to enhance animals growth. Among the most studied supplements there are the probiotics, prebiotics and symbiotics that has been tested in various nonruminants animals (BRITO et al., 2013) Probiotic's activity provides scientific bases associated with increased protective function against pathogenic microorganisms in young chickens (LEE et al., 2010).

Based on this collection of information, this study had as an objective to evaluate the effectiveness of the probiotic supplementation using Bacillus subtillisin rations, upon the carcass yield and intestinal parameters of colonial male chicken from the Peeled Neck lineage.

\section{MATERIAL AND METHODS}

This experiment took place in the Federal Institute of Minas Gerais campus Bambuí from January to March of 2016, using 210 broiler chickens with one day of age, from the Peeled Neck lineage. The animals received vaccine against Marek in the incubatory. After its submission, the project went through analyze and received approval by the animal ethics committee (CEUA) from the University José do RosárioVellano (UNIFENAS), protocoled under the number $13 \mathrm{~A} / 2015$.

The probiotic used was founded with Bacillus subtillis $\left(1 \times 10^{9} \quad \mathrm{UFC} / \mathrm{g}\right) \quad \mathrm{DSM}$ $15.544(30 \%)$ and calcium carbonate 
(70\%), serving the treatments to the birds from the first to the $90^{\text {th }}$ day of age.

On the first 30 days, the birds received housing in a conventional experimental shed for broiler chickens. Vaccination programs adopted on the further ages were the ones as proposed on the lineage's handling manual. To compose the beds crushed rice husk was the substrate exploited, that was reutilized only once in a commercial lot of broiler's chicken.

The experimental shed has 48 boxes divided into two lateral lines, with 24 boxes per line and individual area of 2,16 square meters each plot. This shed went through a period of 15 days with no animals in it for sanitary measures, dry cleaning, humid cleaning using detergent in the water, rinse and disinfection with appliance of quaternary ammonia to $10 \%$ concentration.

Systems of external curtains in the laterals including mechanic ratchets type activation, positive pressure ventilation system and nebulization system for the control of internal temperature and humidity composed the shed set of equipments.

The transfer of the birds to the experimental pickets occurred after they completed 30 days of age. Each experimental picket had an area of $77,35 \mathrm{~m}^{2}$, including an area to mobile shelter covered by raffia canvas and utile area of $10 \mathrm{~m}^{2}$, where ensued the installation of pendulum water drinkers, tubular adult feeders and perch. Tifton 85 was the forage utilized.

Following MAPA's (Ministry of Agriculture, Livestock and Purveyance) recommendation (Circular Letter number, 4, 1998), a minimum of 3 $\mathrm{m}^{2}$ picket area per bird after 30 days until 90 days of age was provided, disregarding the shelter's area.
There was a usage of an alimentary program comprehending 4 diets, with distribution in the following forms: initial ration (1 to 29 days), growth I (30 to 49 days), growth II (50 to 80 days) and finishing (81 to 90 days). All the diets, according to the raising phase, were isoenergetic, isoproteic, isoaminoacidic, isocalcic, and isophosphoric, as shown on Table 1.

There ration provision was ad libitum throughout the animals live, and offered in bran form free from chemical growth promoters, anticoccidials and animal origin ingredients.

The distribution of the treatments were by completely randomized design, with 2 treatments (ration supplemented with $300 \mathrm{~g} \mathrm{t}^{-1}$ of commercial probiotic and ration without supplementation), and 5 repetitions including 21 birds each.

The slaughtering and collection of samples occurred at the $90^{\text {th }}$ day of age of the broiler's hicks following a methodology proposed by Loddi et al. (2000). Previously the slaughter the birds had fasting for 10 hours (only ration), afterwards there was a selection, weighting and identification of 3 birds per plot who presented medium weight in an interval of $\pm 10 \%$ of the medium weight of the experimental unity. Those birds went to the slaughter house and were slaughtered according to the implemented routine.

Electronarcosis was the method used to stun the animals, with manual bleeding following immediately by cutting the jugular vein.

Prior cutting off the feet and neck there was the weighting of the carcass. Subsequently they were weighted in scales with capacity for $15 \mathrm{~kg}$ (Toledo, model: 9094) so the yield of the carcass could be calculated and the division of the cuts could proceed. 
Table 1. Experimental diets to different production phases of country-type Peeled Neck male chicken ( 1 to 29,30 to 49,50 to 80 and 81 to 90 days of age), supplemented or not withBacillus subtillisprobiotic

\begin{tabular}{|c|c|c|c|c|c|c|c|c|}
\hline Ingrediente & $\begin{array}{c}C^{*} \\
1-29\end{array}$ & $\begin{array}{l}\mathrm{P}^{* *} \\
1-29\end{array}$ & $\begin{array}{c}C^{*} \\
30-49\end{array}$ & $\begin{array}{c}\mathrm{P}^{* *} \\
30-49\end{array}$ & $\begin{array}{c}C^{*} \\
50-80\end{array}$ & $\begin{array}{c}\mathrm{P}^{* *} \\
50-80\end{array}$ & $\begin{array}{c}C^{*} \\
81-90\end{array}$ & $\begin{array}{c}\mathrm{P}^{* *} \\
81-90\end{array}$ \\
\hline Corn grain $7 \%$ & 63,85 & 63,85 & 65,94 & 65,94 & 69,24 & 69,24 & 71,25 & 71,25 \\
\hline $\begin{array}{l}\text { Soybean } \\
\text { meal } 46 \%\end{array}$ & 31,90 & 31,90 & 29,50 & 29,50 & 25,60 & 25,60 & 24,10 & 24,10 \\
\hline Soybean oil & - & - & 0,50 & 0,50 & 1,40 & 1,40 & 1,60 & 1,60 \\
\hline Calcareous & 1,50 & 1,50 & 1,50 & 1,50 & 1,30 & 1,30 & 0,95 & 0,95 \\
\hline Common salt & 0,40 & 0,40 & 0,40 & 0,40 & 0,40 & 0,40 & 0,40 & 0,40 \\
\hline $\begin{array}{l}\text { Dicalcium } \\
\text { phosphate }\end{array}$ & 1,85 & 1,85 & 1,70 & 1,70 & 1,60 & 1,60 & 1,35 & 1,35 \\
\hline Probiotic $^{1}$ & - & 0,03 & - & 0,03 & - & 0,03 & - & 0,03 \\
\hline Kaolin & 0,03 & - & 0,03 & - & 0,03 & 0,03 & 0,03 & - \\
\hline $\begin{array}{l}\text { DL- } \\
\text { Methionine }\end{array}$ & 0,22 & 0,22 & 0,21 & 0,21 & 0,21 & 0,21 & 0,13 & 0,13 \\
\hline Choline $60 \%$ & 0,05 & 0,05 & 0,04 & 0,04 & 0,04 & 0,04 & 0,03 & 0,03 \\
\hline $\begin{array}{l}\text { Vitamin } \\
\text { Premix }\end{array}$ & 0,10 & 0,10 & 0,10 & 0,10 & 0,10 & 0,10 & 0,10 & 0,10 \\
\hline $\begin{array}{l}\text { Mineral } \\
\text { Premix }^{3}\end{array}$ & 0,10 & 0,10 & 0,08 & 0,08 & 0,08 & 0,08 & 0,06 & 0,06 \\
\hline Total: & 100 & 100 & 100 & 100 & 100 & 100 & 100 & 100 \\
\hline $\begin{array}{l}{ }^{1} \text { Concentration } \\
\text { DSM } 15.544 \text { (3 } \\
{ }^{2} \text { Warranty lev } \\
\text { (minimum.) } 12 \\
\text { 143,7g; Niacin } \\
8.800 .000,0 \mathrm{UI} \text {; } \\
\text { mg; Zn } 50 \mathrm{mg} \text {; } \\
{ }^{3} \text { Warranty leve } \\
\text { iodine (minimur } \\
\text { C }^{*} \text { Control treat } \\
\mathrm{P}^{* *} \text { Treatment }\end{array}$ & $\begin{array}{l}\text { of } B a c \\
\% \text { ) and } \\
\text { ls per } \\
000,00 \\
\text { (minim } \\
\text { Vitamin } \\
\text { cu } 8 \mathrm{mg} \\
\text { s per } \mathrm{k} \\
\text { a) } 1.500 \\
\text { ment }(\%)\end{array}$ & $\begin{array}{l}\text { ssubtill } \\
\text { cium C } \\
\text { of vita } \\
\text { Bioti } \\
40.00 \\
\text { (minir } \\
75 \mathrm{mg} \\
\text { f miner } \\
\text { ng; mar }\end{array}$ & $\begin{array}{l}\text { robiotic } \\
\text { onate }(70 \\
\text { n premix } \\
\text { minimun } \\
\text { mg; S } \\
\text { n.) } 2.500 \\
50 \mathrm{mg} \text {. } \\
\text { premix: } \\
\text { nse (min }\end{array}$ & $\begin{array}{l}\mathrm{x} 10^{9} \mathrm{UF} \\
\text { Folic Ac } \\
77,0 \mathrm{mg} \\
\text { ium (m } \\
\text { mg; Gro } \\
\text { oper (mi } \\
\text { Im) } 67,5 \\
\text { obiotic ( }\end{array}$ & $\begin{array}{l}\text { g). } 300 \mathrm{~g} / \\
\text { (minims } \\
\text { Calcium } \\
\text { mum.) } 3 \\
\text { h vitamin } \\
\text { num.) } 7 .( \\
\text { zinc (mir } \\
10^{9} \mathrm{UFC} /\end{array}$ & $\begin{array}{l}\text { Compo } \\
\text { 900,0 } \\
\text { inimum. } \\
0 \mathrm{mg} \text {; } \\
04 \mathrm{~g} \text {; An } \\
, 0 \mathrm{mg} \text {; I } \\
\text { um.) } 45 \text {, } \\
\text { (\%). }\end{array}$ & $\begin{array}{l}\text { on: } \mathrm{Bact} \\
\text {; Panto } \\
\text { maximu } \\
\text { amin A } \\
\text { kidant } 0 \text {, } \\
\text { (minim }\end{array}$ & $\begin{array}{l}\text { s subtilis } \\
\text { nic Acid } \\
130,0- \\
\text { inimum) } \\
\text { g; Mn } 75 \\
50,0 \mathrm{~g} \text {; }\end{array}$ \\
\hline
\end{tabular}

During evisceration, there was the collection of the edible viscera, inedible viscera and abdominal fat. The viscera considered as edible was liver, gizzard and heart; the fat counting as abdominal fat was all the fat on the retroperitoneal region, including those involving the gizzard; and as inedible viscera there were considered the spleen, small intestine (duodenum, jejunum and ileum) and large intestine (cecum and colon).

All the viscera were weighted in semianalytic scales (BL series; Brand: Shimadzu; model: BL 3200H) with capacity to $3200 \mathrm{~g}$ and precision of 0,01 g.

The division of the carcass cuts from each plot formerly identified were weighted in two moments: with feet, head and neck; and then without feet, head and neck, after the procedure of primary commercial cuts (breast, wings, thighs and upperlegs) and its respective weightings.

On the yield calculus, there were considered as: breast - the muscular tissue with skin, the sternum (breastbone) and clavicle; thighs - the muscular tissue with skin, tibia and fibula bones; upperlegs - the muscular 
tissue with skin, femur and patella bones; set of wings - the muscular tissue with skin and bones.

Likewise, for the carcass study, there was the assessment of the live weight in the moment of the slaughter; weight of the carcass with feet, head and neck; weight of the carcass without feet, head and neck; thighs; upperlegs; breast; wings; edible and inedible viscera; and abdominal fat.

In order to determinate the live weight, measured right before the slaughter, 3 birds were used to each repetition. The calculation of the values for live weight were stipulated through the medium weight of 3 animals, that represented one experimental unity, corresponding to the formula: $\mathrm{LWv}=$ weight of the plot (3 birds) $/ \mathrm{n}$.

Later on, the carcass with feet, head and neck had its weight measured after taking off the viscera and abdominal fat. The calculation of the weight values of the carcass were provided by the medium value of 3 carcasses that represented each plot, following the formula: $\mathrm{CW} / \mathrm{c}=$ weight of the plot $(3$ carcasses) $/ \mathrm{n} 3$.

Furthermore, the evaluation of the carcass weight without feet, head and neck was conducted after the removal of the feet, head and neck. The calculation of the weight values of the carcass were provided by the medium value of 3 carcasses that represented each plot, following the formula: $\mathrm{CW}=$ weight of the plot (3 carcasses)/n3.

The carcass yield and abdominal fat: as carcass yield (CY) there was taken under consideration the association among the carcass weight without feet and head (WFH) and the live weight $(\mathrm{LWv})$, as in accord to the formula: $\mathrm{CY}=\mathrm{CW} / \mathrm{LWv} * 100$. The determination of abdominal fat yield (AFa) had its values calculated by the abdominal fat weight (FW) in consideration to the live weight, conforming the formula: $\mathrm{AF}=\mathrm{FW} / \mathrm{LW}$ $* 100$.

The calculation of the yield of the main cuts were conferring the weight of the cut of each one of the birds from each plot. The cuts yield (breast, thigh, uppeleg and wings) took in consideration the relation between the medium weight of the cut representative of every repetition and the carcass weight without feet and head, meeting the formula: $\mathrm{CY}=\mathrm{PX} / \mathrm{CW} * 10$

Moreover the estimation of the secondary cuts yield and parts of the gastrointestinal system parts were realized through the edible secondary cut's weight: heart, liver, gizzard; and parts of the gastrointestinal system: goiter, proventriculus, spleen, small intestine (duodenum, jejunum, ileum) and large intestine (cecum and colon). To the calculation it was used the weight of every one of the variables analyzed in the plot in the relation amid medium weight of the live weight (LW), as shown in the formula: Cut yield/ gastrointestinal system $=\mathrm{PX} /$ LW * 100. In agreement to proposed methodology by Awad et al. (2009).

So as to examine gizzard's weight, there was the removal of fed that was left in the organ, keeping the keratin that surrounds it. For the inedible cuts (goiter, proventriculus, duodenum, jejunum, ileum, cecum and colon), a soft compression was applied in order to eliminate the interior content, so the clean tissue would be weighted in a scale with $0,5 \mathrm{~g}$ precision.

After identification of each tissue proceeded the collection and reservation of those for further analysis. The small intestine's length measurement as well as for every segment progressed subsequently to the emptying of the intestinal content. 
The use of a $30 \mathrm{~cm}$ roller (with precision of $0,1 \mathrm{~mm}$ ) assisted the measurements. To obtain relative length values, the measurement of each segment were divided by the total length of the small intestine, being the result multiplied by 100 .

In regard of the $\mathrm{pH}$ of the content from each compartment of the gastrointestinal tract, one bird at time per plot in fasting, was weighted and slaughtered by cervical dislocation, in a total of 10 individuals for $\mathrm{pH}$ analysis. All the procedures to obtain the $\mathrm{pH}$ of the content of every compartment of the gastrointestinal tract was conferring as suggested by Wu et al. (2013).

Immediately after the slaughter of the birds, the viscera was exposed, so the organs necessary to the analysis could be identified: goiter, proventriculus, gizzard, duodenum, jejunum, ileum, cecum and colon.

The Digital Microprocessor of benchpHmeter, model DLA-pH, Del Lab brand, was the device used to estimate the $\mathrm{pH}$ values. Previously calibrated following fabricant's recommendations.

Subsequent to the identification of each segment of the gastrointestinal tract, the content was collected in plastic recipients and then weighted, allowing a dilution in 10 times using deionized water. The recipient holding the solution of the intestinal content and distillated water was closed and agitated for about 5 seconds.

The electrode was immerged into the solution and the $\mathrm{pH}$ value was collected once as the value on the pHmeter were stable. This technique was redone with one bird at time, in other words, at the end of the collection of $\mathrm{pH}$ values from the intestinal content of one bird, advanced to the slaughter of the next one.

The data was submitted to variance analysis and the means of treatment compared by Tukey test with 5\% of probability through the statistical program SISVAR (FERREIRA, 2000), and $F$ test to comparison of the former treatments to the control treatment.

\section{RESULTS AND DISCUSSION}

The results for carcass yield, breast, thighs, upperleg and wings (Table 2) did not present significant differences $(\mathrm{P}>0,05)$ from the treatments regarding those variables.

Table 2. Whole carcass yield, prepared carcass, breast, thigh, upperleg and wings of hick broilers Peeled Neck at 90 days of age submitted to diets suplemented or not with probiotic Bacillussubtillis

\begin{tabular}{lcccccc}
\hline \multirow{2}{*}{ Item } & \multicolumn{7}{c}{ Yield(\%) } \\
\cline { 2 - 7 } & Whole Carcass $^{*}$ & Prepared Carcass $^{* *}$ & Breast & Thigh & Upperleg & Wing \\
\hline Control $^{1}$ & 84.77 & 72.37 & 29.10 & 16.54 & 18.020 & 11.90 \\
Probiotic $^{2}$ & 84.73 & 72.99 & 29.34 & 16.58 & 18.027 & 12.02 \\
P Value $^{3}$ & 0.9551 & 0.3566 & 0.6114 & 0.9322 & 0.9754 & 0.5769 \\
VC\% $^{4}$ & 1.18 & 1.37 & 2.47 & 3.91 & 2.17 & 2.94 \\
\hline
\end{tabular}

${ }^{*}$ Whole carcass includes feet, head and neck; ${ }^{* *}$ Prepared carcass excludes feet, head and neck.

${ }^{1}$ Control diet without addition of probiotic; ${ }^{2}$ Diet with addition of probiótico Bacillus subtillis DSM $15.544\left(1 \times 10^{9} \mathrm{UFC} / \mathrm{g}\right) 300 \mathrm{~g} / \mathrm{ton} .3^{3} \mathrm{P}$ value = probability of the effect (or the difference) observed amid the treatments; ${ }^{4} \mathrm{VC}=$ Variation Coefficient $(\%)$. 
The obtained results are similar to the ones found by Loddi et al. (2000); Batista et al. (2007); Lorençon et al. (2007) and Godoi et al. (2008), that did not verify effect of the usage of antibiotics, prebiotics, probiotics and symbiotics in hick broiler's rations over the carcass yield and the commercial cuts. These authors relate that various factors can intervene on additives efficacy; therefore, many times the results are contradictory. Environment, sanitary challenge, the animal's physiology, species are some of the topics to be focused on probiotic evaluation on diets.

Corrêa et al. (2003) did not observe difference in between the treatments ( $p>0,05)$ involving live weight and carcass yield, of breast and abdominal fat, while evaluating the effect of the probiotics over performance and carcass yield of hick broilers. The authors disclose that the efficiency of the probiotic can be relatively linked to the actions to improve intestinal health; however, in some cases those agents may or may not suffer interference of external agents.

For this particular study it is believed that the microbiologic challenge was not enough so the product would show its deed.

Dalólio et al. (2015) did not find significant differences in the inclusion of varied additives as an alternative to the antimicrobials in hick broiler's diet, in relation to the carcass yield and the cuts, as in the present study.

On the other hand, Albino et al. (2006) witnessed an upgrading on breast yield, breast fillet and legs as they used prebiotics in hick broiler's diet. Comparatively, Rocha et al. (2010), utilizing prebiotics, organic acids and probiotics in rations to hick broiler's obtained better breast yield in comparison to those who received ration without additives.

Mozer da Silva et al. (2011) did not find statistical meaning differences on cut yields to chicken from Cobb 500 lineage, supplemented with rations containing antibiotic and probiotic as a substitute. These authors concluded that the use of probiotic as growth promoter can be used as a substitute to antibiotics without compromising animal's performance.

In the present research it was presumed that good hygienic-sanitary conditions minimizes probiotic's action, as it needs sanitary challenge to express its effectiveness. The variable for gizzard, heart, liver and abdominal fat yields were not influenced $(\mathrm{P}>0,05)$ by the supplementation with probiotic on Peeled Neck chicken's ration at 90 days of age (Table 3 ).

Table 3. Relative organs and abdominal fat weight regarding live weight of hick broilers of the Peeled Neck at 90 days of age submitted to diets that were supplemented or not with probiotic Bacillus subtillis

\begin{tabular}{lcccccccc}
\hline \multirow{2}{*}{ Item } & \multicolumn{1}{c}{ Yield $(\%)$} \\
\cline { 2 - 9 } & Gut & Proventriculus & Gizzard & Heart & Liver & Spleen & Cecum & Fat \\
\hline Control $^{1}$ & 0.68 & 0.27 & 1.210 & 0.4382 & 1.4845 & 0.1550 & 0.3203 & 2.74 \\
Probiotic $^{2}$ & 0.66 & 0.26 & 1.214 & 0.4314 & 1.4148 & 0.1651 & 0.3203 & 2.83 \\
P value $^{3}$ & 0.6151 & 0.5091 & 0.9549 & 0.7345 & 0.1594 & 0.5692 & 0.1335 & 0.7359 \\
VC $\%^{4}$ & 8.11 & 6.88 & 8.94 & 6.97 & 4.90 & 16.94 & 7.25 & 15.02 \\
\hline
\end{tabular}

${ }^{1}$ Control diet without probiotic; ${ }^{2}$ Diet with the addition of the probiotic Bacillus subtillisDSM 15.544 $\left(1 \times 10^{9} \mathrm{UFC} / \mathrm{g}\right) 300 \mathrm{~g} / \mathrm{ton} . ;{ }^{3} \mathrm{P}$ value $=$ probability of the effect (or the difference) observed within the treatments; ${ }^{4} \mathrm{VC}=$ variation coefficient (\%). 
Barroso et al. (2017), perceived that for the variables of yield for different meat cuts (head, neck, feet, thighs, wings, liver, gizzard, breast) there was no significant effect on the replacement of the use of growth promoters additives in favor of probiotics in hick broilers from the Peeled Neck's ration in the period from 1 to 75 days.

Paz et al. (2010), showed that using antibiotics, prebiotics, probiotics and organic acids in bird's diet did not enhance breast and thigh's yield and did not influence liver, heart and intestine's weight either.

Holanda et al. (2015) raised males Peeled Neck in conventional systems, fed with commercial ration, slaughter at 84 days old, with heard and liver's yield comparable, and greater gizzard yield, (respectively $0,57 \%, 1,92 \%$ and 3,60 $\%)$ in resemblance to this research Mohan et al. (1996) did not observe difference in heart, spleen, liver and gizzard's yield by using probiotics as well.

Faria et al. (2009); Souza et al. (2011); Santos et. al. (2004) did not detect differences in carcass yield and meat cuts through usage of antibiotic and probiotic as growth promoters, corroborating with the present study.

As stated by Pelicano et al. (2005), various questions have been broached about the utilization of these additives in relation to meet quality. The authors believe that using such products is advantageous to improve meat quality and its carcass; nevertheless, they emphasize that there are still many controversial results concerning this matter, since external factors such as handling at slaughter, distress and mostly sanitary challenge can have a direct influence at this product's efficacy, and as a consequence, in meat quality.

Length and relative weight from the segments of small intestine values did not present meaningful difference at 90 days of age of the birds (Table 4). Nunes et al. (2009), while evaluating intestinal morphology of hick broilers fed with ration containing additives other than antimicrobials and Pelicano et al. (2005) while testing probiotic (Bacillus subtilis and bacterial pool) and MOS in hick broilers at 42 days did not find positive effects for any morphologic parameters evaluated on none of the intestine segments.

Table 4. Relative length and weight (in grams) of smallintestine segments of Peeled Neck hick broilers at 90 days of age under diets, supplemented or not with Bacillus subtillisprobiotic

\begin{tabular}{lcccccccc}
\hline \multirow{2}{*}{ Item } & \multicolumn{3}{c}{ Relative Length (\% in cm) } & & \multicolumn{3}{c}{ Relative Weight (\% in gr) } \\
\cline { 2 - 4 } \cline { 6 - 8 } \cline { 6 - 8 } & Duodenum & Jejunum & Ileum & & Duodenum & Jejunum & Ileum \\
\hline Control $^{1}$ & 17.72 & 40.48 & 41.24 & & 0.3572 & 0.7722 & 0.80 \\
Probiotic $^{2}$ & 18.87 & 39.31 & 42.02 & & 0.3472 & 0.8189 & 0.7981 \\
P Value $^{3}$ & 0.06 & 0.2512 & 0.3768 & & 0.7726 & 0.2195 & 0.97 \\
VC $^{4}$ & 4.61 & 3.73 & 3.14 & & 6.96 & 6.97 & 9.57 \\
\hline
\end{tabular}

${ }^{1}$ Controle diet without probiotic addition $;^{2}$ Diet with addition of the probiotic Bacillus subtillisDSM $15.544\left(1 \times 10^{9} \mathrm{UFC} / \mathrm{g}\right) 300 \mathrm{~g} / \mathrm{ton} . ;^{3} \mathrm{P}$ value = probability of effect (or difference) observed among the treatments; ${ }^{4} \mathrm{VC}=$ Variation Coefficient $(\%)$. 
Barroso et al. (2017) correspondingly to the other authors, also did not find effects to the intestine weight thru the substitution of growth promoter additives pro probiotics in Peeled Neck hick broiler's ration throughout the period of 1 to 75 days.

The results referents to gastrointestinal morphology may not have been evidenced due to the facts that were already mentioned, as the non-sufficient sanitary challenge provided by the use of reutilized beds to enhance the deed of the probiotic Bacillus subtillis.
The $\mathrm{pH}$ measurement was not statistically different $(\mathrm{P}>0,05)$ to most of the analyzed compartments, except for the $\mathrm{pH}$ at the digest present in the proventriculus and at the jejunum (Table 5). Guts microbiota and some pathogenic agents that are $\mathrm{pH}$ sensible influence gastrointestinal content's $\mathrm{pH}$. Furthermore, researches have demonstrated the impact of lactic acid's bacteria over the $\mathrm{pH}$, influencing pathogenic agent's population (ALAKOMI et al., 2000).

Table 5. Measurements of the $\mathrm{pH}$ of the gastrointestinal compartments of Peeled Neck hick broilers at 90 days of age under diets supplemented or not with Bacillussubtillis probiotics

\begin{tabular}{|c|c|c|c|c|}
\hline Segment & Treatment & $\mathrm{pH}$ & ${ }^{3} \mathrm{P}$ Value & ${ }^{4} \mathrm{VC} \%$ \\
\hline Goiter & $\begin{array}{l}\text { Control }^{1} \\
\text { Probiotic }^{2}\end{array}$ & $\begin{array}{l}4.69 \\
4.66\end{array}$ & 0.7125 & 2.83 \\
\hline Proventriculus & $\begin{array}{l}\text { Control }^{1} \\
\text { Probiotic }^{2}\end{array}$ & $\begin{array}{l}3.86 \\
4.37 \\
\end{array}$ & $0,0209 *$ & 6.91 \\
\hline Gizzard & $\begin{array}{l}\text { Control }^{1} \\
\text { Probiotic }^{2}\end{array}$ & $\begin{array}{l}3.87 \\
4.02 \\
\end{array}$ & 0.2641 & 5.0 \\
\hline Duodenum & $\begin{array}{l}\text { Control }^{1} \\
\text { Probiotic }^{2}\end{array}$ & $\begin{array}{l}6.25 \\
6.32 \\
\end{array}$ & 0.6033 & 3.16 \\
\hline Jejunum & $\begin{array}{l}\text { Control }^{1} \\
\text { Probiotic }^{2} \\
\end{array}$ & $\begin{array}{l}5.98 \\
6.27 \\
\end{array}$ & $0.0203 *$ & 2.54 \\
\hline Ileum & $\begin{array}{l}\text { Controle }^{1} \\
\text { Probiotic }^{2}\end{array}$ & $\begin{array}{l}6.74 \\
7.09\end{array}$ & 0.1651 & 5.26 \\
\hline Cecum & $\begin{array}{l}\text { Control }^{1} \\
\text { Probiotic }^{2}\end{array}$ & $\begin{array}{l}7.00 \\
7.10\end{array}$ & 0.7518 & 6.30 \\
\hline
\end{tabular}

*Means of the treatments in the column of the study period are statistically diferente by the $\mathrm{F}$ test $(\mathrm{P}<0,05)$.

${ }^{1}$ Controle diet antibiotic free; ${ }^{2}$ Diet with addition of the probioticBacillus subtillisDSM $15.544\left(1 \times 10^{9}\right.$ $\mathrm{UFC} / \mathrm{g}$ ) 300g/ton.; ${ }^{3} \mathrm{P}$ Value $=$ probability of effect (or difference) observed mid treatments; ${ }^{4} \mathrm{VC}=$ variation coefficient $(\%)$.

Faria et al. (2009) did not verify significant interaction among the additives and organic acids magistrate in hick broiler's ration at 45 days of age, over goiter, duodenum and cecum's $\mathrm{pH}$, results encountered in this research as well.

The $\mathrm{pH}$ values observed on the goiter are within the range indicated by Faria et al. (2009), which goes from 4,0 to 5,0 ; and the duodenum is preconized from 5,0 to 6,0 .

Knarreborg et al. (2008) indicate that the agent Bacillusspp can increase the number of lactic acid bacteria, conducing to $\mathrm{pH}$ drop. However, such alterations were not witnessed in this 
research in any of the evaluated compartments.

The inclusion of $300 \mathrm{~g} / \mathrm{ton}$. of the probiotic Bacillus subtilisDSM 15.544 on the diet of Peeled Neck hick broilers did not influence the carcass yield, the $\mathrm{pH}$ and morphology of the gastrointestinal compartments of the birds during the period of experimentation and at the levels tested in this study. The sanitary challenge was not enough to demonstrate the deed of the probiotic.

\section{ACKNOWLEDGEMENTS}

The authors would like to thank the Federal Institute of Minas Gerais for the support and help that enabled the execution of this experiment, the Uniquimica company for providing the tested product.

\section{REFERÊNCES}

ALBINO, L.F.T.; FERES, F.A.; DIONIZIO, M.A.; ROSTAGNO, H.S.; VARGAS JÚNIOR, J.G.; CARVALHO, D.C.O.; COSTA, C. Uso de prebióticos à base de mananoligossacarídeoem rações para frangos de corte. Revista Brasileira de Zootecnia, v.35, n.3, p.742-749, 2006.

ALAKOMI, H.L.; SKYTTÄ, E.; SAARELA, M.; MATTILASANDHOLM, T.; LATVA-KALA, K.; \&HELANDER, I.M.. Lactic acid permeabilizes gram-negative bacteria by disrupting the outer membrane.

Applied and environmental microbiology, v.66, n.5, p.2001-2005, 2000 .
AWAD, W.A.; GHAREEB, K.; ABDELRAHEEM, S.; BÖHM, J. Effects of dietary inclusion of probiotic and synbiotic on growth performance, organ weights, and intestinal histomorphology of broiler chickens. Poultry Science, v.88, p.49-56, 2009.

BARROSO, J.R.; FERREIRA, A.H.C.; DA SILVA, A.B.M.; ARAÚJO, M.S.; OLIVEIRA, L.T.S. Probiótico na dieta de frangas da linhagem Pescoço pelado no período de 1 a 75 dias de idade. Revista Nutritime, v.13, n.4, p.6012-6018, 2017.

BATISTA, L.S.; GARCIA, E.A.; FAITARONE, A.B.G.; SHERER, M.R.; MORI, C.; PELICIA, K.; PIZZOLANTE, C.C.

Flavonoidsandmannanoligosaccharides in broiler diets. Revista Brasileira de

Ciência Avícola, v.9, n.1, p.33-37, 2007.

DE BRITO, J.M.; FERREIRA, A.H.C.;

JUNIOR, A.; ARARIPE, M.; LOPES, J.; DUARTE, A.; RODRIGUES, V.

Probióticos, prebióticos e simbióticos na alimentação de não-ruminantes-revisão.

Revista Eletrônica Nutritime, v.11, n.1, p.3070-3084, 2014.

CORRÊA, G.S.S.; GOMES, A.V.C.; CORRÊA, A.B.; SALLES, A.S.;

MATTOS, E.S. Efeito de antibiótico e probióticos sobre o desempenho e rendimento de carcaça de frangos de corte. Arquivo Brasileiro de Medicina Veterinária e Zootecnia, v.55, n.4, p.467-473, 2003.

DALÓLIO, F.S.; MOREIRA, J.; VALADARES, L.R.; NUNES, P.B.; VAZ, D.P.; PEREIRA, H.J.; DA CRUZ, P.J. Aditivos alternativos ao uso de antimicrobianos na alimentação de frangos de corte. Revista Brasileira de Agropecuária Sustentável, v.5, n.1, p.86-94, 2015. 
FARIA, D.E.; HENRIQUE, A.P.F.;

NETO, R.F.; MEDEIROS, A.A.; JUNQUEIRA, O.M.; FARIA FILHO, D.E. de. Alternativas ao uso de antibióticos como promotores de crescimento para frangos de corte: 2 . Ácidos orgânicos e probióticos. Ciência Animal Brasileira, v.10, n.1, p.29-39, 2009.

\section{FERREIRA, D.F. SISVAR: Sistema} para análise de variância para dados balanceados: programa de análises estatísticas e planejamento de experimentos. Versão 4.3. Lavras: UFLA, 2000.

HELLMEISTER FILHO, P.; MENTEN, J.F.M.; SILVA, M.A.N.D.; COELHO, A.A.D.; SAVINO, V.J.M. Efeito de genótipo e do sistema de criação sobre o desempenho de frangos tipo caipira. Revista Brasileira de Zootecnia, v.32, n.6, p.1883-1889, 2003.

HOLANDA, M.A.C.; HOLANDA, M.C.R. de; VIGODERES, R.B.; JUNIOR, W.M.D.; ALBINO, L.F.T. Desempenho de frangos caipiras alimentados com farelo integral de mandioca. Revista Brasileira de Saúde e Produção Animal [online], v.16, n.1, p.106-117, 2015.

KNARREBORG, A.; BROCKMANN, E.; HOYBYE, K.; KNAP, I.; LUND, B.; MILORA, N.; LESER, T.D. Bacillus subtilis (DSM17299) modulates the ileal microbial communities and improves growth performance in broilers. International Journal of Probiotics and Prebiotics, v.3, p.83-88, 2008.
LIMA, A.C.F.D.; PIZAURO JÚNIOR, J.M.; MACARI, M.; MALHEIROS, E.B. Efeito do uso de probiótico sobre o desempenho e atividade de enzimas digestivas de frangos de corte. Revista Brasileira de Zootecnia, v.32, n.1, p.200-207, 2003.

LEE, K.W.; LI, G.; LILLEHOJ, H.S.; LEE, S.H.; JANG, S.I.; BABU, U.S.; SIRAGUSA, G.R. Bacillus subtilisbased direct-fed microbials augment macrophage function in broiler chickens. Research in Veterinary Science, v.91, n.3, p.87-91, 2011.

LODDI, M.M.; GONZALES, E.; TAKITA, T.S.; MENDES, A.A.; ROÇA, R.D.O. Uso de probiótico e antibiótico sobre o desempenho, o rendimento e a qualidade de carcaça de frangos de corte. Revista Brasileira de Zootecnia, v.29, n.4, p.1124-1131, 2000 .

LORENÇON, L.; NUNES, R.V.; POZZA, P.C.; SANTOS POZZA, M.S. dos; APPELT, M.D.; SILVA, W.T.M. da. Utilização de promotores de crescimento para frangos de corte em rações fareladas e peletizadas. Acta Scientiarum. Animal Sciences, v.29, n.2, p.151-158, 2007.

MOHAN, B.; KADIRVEL, R.; NATARAJAN, A.; BHASKARAN, M. Effect of probiotic supplementation on growth, nitrogen utilisation and serum cholesterol in broilers. British Poultry Science, v.37, n.2, p.395-401, 1996.

NAZARENO, A.C.; PANDORFI, H.; GUISELINI, C.; VIGODERIS, R.B.; PEDROSA, E.M.R. Bem-estar na produção de frango de corte em diferentes sistemas de criação.

Engenharia Agrícola, v.31, n.1, p.1322, 2016. 
NUNES, A.D.; VAZ, A.C.N.; RASPANTINI, L.E.R.; SILVA, E.M.D.; ALBUQUERQUE, R.D. Desempenho e morfologia intestinal de frangos de corte alimentados com rações contendo aditivos alternativos a antimicrobianos. Brazilian Journal of Veterinary Research and Animal Science, v.46, n.6, p.500-506, 2009.

PAZ, A.S.D.; ABREU, R.D.; COSTA, M. do C.M.M. da; LUZ JAEGER, S.M.P.; ROCHA, A.P.D.; FERREIRA, B.P.; CAMPOS, B.M. Aditivos promotores de crescimento na alimentação de frangos de corte. Revista Brasileira de Saúde e Produção Animal, v.11, n.2, p.395402, 2010.

PEDROSO, A.A.; MENTEN, J.F.; LAMBAIS, M.R.; RACANICCI, A.M.C.; LONGO, F.A.; SORBARA, J.O.B. Intestinal bacterial community and growth performance of chickens fed diets containing antibiotics. Poultry Science, v.85, n.4, p.747-752, 2006.

PELICANO, E.R.L.; SOUZA, P.A.; SOUZA, H.B.A.; FIGUEIREDO, D.F.; BOIAGO, M.M.; CARVALHO, S.R.; BORDON, V.F. Intestinal mucosa development in broiler chickens fed natural growth promoters. Revista Brasileira de Ciência Avícola, v.7, n.4, p.221-229, 2005.

ROCHA, A.P. da; ABREU, R.D.; COSTA, M. do C. M.M. da; OLIVEIRA, G.J.C. de; ALBINATI, R.C.B.; PAZ, A.S. da; PEDREIRA, T.M. Prebióticos, ácidos orgânicos e probióticos em rações para frangos de corte. Revista Brasileira de Saúde e Produção Animal [online], v.11, n.3, p.793-801, 2010.
SANTOS, I.I.; POLI, A.; PADILHA, M.T.S. Desempenho zootécnico e rendimento de carcaça de frangos de corte suplementados com diferentes probióticos e antimicrobianos. Acta Scientiarum. Animal Sciences, v.26, n.1, p.29-33, 2004.

SILVA, W.T.M. da; NUNES, R.V.; POZZA, P.C.; POZZA, M.S. dos S.; APPELT, M.D.; EYNG, C. Avaliação de inulina e probiótico para frangos de corte. Acta Scientiarum. Animal

Sciences, v.33, n.1, p. 19-24, 2011.

SOUZA, L.F.A.D.; ARAUJO, D.N.; ASTOLPHI, J.L.D.L.; AMBIEL, A.C.; SANTOS, L.S.; CARMO, A.J.D.; SILVA, P.C.G.D. Probiótico e antibiótico como promotores de crescimento para frangos de corte.

Colloquium Agrariae, v.6, n.2, p.3339, 2011.

TAKAHASHI, S.E.; MENDES, A.A.; SALDANHA, E.S.P.B.; PIZZOLANTE, C.C.; PELÍCIA, K.; GARCIA, R.G.; QUINTEIRO, R.R. Efeito do sistema de criação sobre o desempenho e rendimento de carcaça de frangos de corte tipo colonial. Arquivo Brasileiro de MedicinaVeterinária e Zootecnia, v.58, n.4, p.624-632.2006.

WU, Q.J.; WANG, L.C.; ZHOU, Y.M.; ZHANG, J.F.; WANG, T. Effects of clinoptilolite and modified clinoptilolite on the growth performance, intestinal microflora, and gut parameters of broilers. Poultry Science, v.92, n.25, p.684-692, 2013.

Data de recebimento: 30/08/2017

Data de aprovação: 14/11/2017 